BLS 33, No 2 2007. DOI: http://dx.doi.org/10.3765/bls.v33i2.3498

(published by the Berkeley Linguistics Society and the Linguistic Society of America)

\title{
Argument Quantification and Qualification in Upper Necaxa Totonac ${ }^{1}$
}

\author{
DAVID BECK \\ University of Alberta
}

\section{Introduction.}

Upper Necaxa Totonac (UNT) has, on the surface, a fairly ordinary parts-ofspeech system with four major word classes - noun, verb, adjective, and adverb. The class of adverbs, however, includes a large number of words denoting property concepts (Beck to appear):

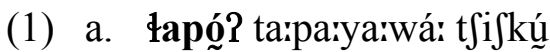

$\begin{array}{lll}\text { lapó? } & \text { ta:pa:-ya:wá: } & \text { t } \int i \int k \underline{\sim} \\ \text { fatly } & \text { side-stand } & \text { man }\end{array}$

'that man is pot-bellied' (LC)

b. kanłít kiłwan?ó:ł t tit jí

$\begin{array}{lll}\text { kanfít } & \text { kił-wan-2o:-1 } & \text { t } \int_{i t} \int_{\sim}^{\prime} \\ \text { showing.teeth } & \text { mouth-Say-TOT-PFV } & \text { dog }\end{array}$

'the dog bared all of its teeth' (LC)

These descriptive adverbs are syntactically distinct from adjectives in that they are exclusively predicate modifiers and they are not potentially adnominal modifiers. Nevertheless, descriptive adverbs are functionally similar to some uses of

\footnotetext{
* Upper Necaxa Totonac, a member of the isolate Totonac-Tepehua language family, is spoken in the Sierra Norte of the state of Puebla, Mexico. Uncited data are from my field notes. I would like to thank my friends in Patla and Chicontla, who have had the good grace and patience to work with me. Thanks are also due to Alexandra Aikhenvald, Judith Aissen, Pamela Munro, Enrique Palancar, and Roberto Zavala for helpful discussion of this paper. The remaining errors are my own. This research was funded by a SSHRC grant to the Upper Necaxa Field Project. The abbreviations used are: 1,2,3 = first-, second-, third-person; ALTV = allative; CLS = classifier; CMT = comitative; $\mathrm{CS}=$ causative , $\mathrm{CTD}=$ containing instrument; $\mathrm{DSD}=$ desiderative; $\mathrm{DTV}=$ determinative; FUT = future; IMPF = imperfective; $\mathrm{INCH}=$ inchoative; INST = instrumental; LOC = locative; $\mathrm{OBJ}=$ object; $\mathrm{PL}=$ plural; $\mathrm{PFV}=$ perfective; $\mathrm{PO}=$ possessive; $\mathrm{PROG}=$ progressive; $\mathrm{QTV}=$ quotative; $\mathrm{SEM}=$ semblative; $\mathrm{SG}=$ singular; $\mathrm{ST} . \mathrm{PL}=$ stative plural; $\mathrm{SUB}=$ subject; $\mathrm{TOT}=$ totalitative .
} 
adjectives in that they attribute a property to one of the arguments of the verb (usually the subject).

It seems likely that the existence of a robust class of descriptive adverbs is related to the inflectional characteristics of the language. These include: the lack of number inflection in the NP; the preferential marking of number of subject and object on the verb; the quantification of subject and object through verbal morphology; and the marking of semantic roles of objects by verbal morphology. Taken together, these facts paint a picture of a language that preferentially quantifies and qualifies NPs through inflectional and syntactic operations on sentential predicates, an extreme variation on the strategy of head-marking in the sense of Nichols (1986).

\section{Descriptive Adverbs}

Adverbs in UNT, in addition to encompassing the usual expressions of time, manner, and place, include expressions of other types of meaning as well. The most relevant of these are the descriptive adverbs, which express property concepts (Thompson 1988):

(2) t faláx 'brittle, fragile'

t $\hat{\imath} p \int^{\text {'d }}$ dense'

t $f i: \int^{\prime}$ 'blurry'

Po:ntó:A 'curly, twisted, tangled'

lampú:F 'wet'

tamán' 'rounded, full'

f'anán 'red or yellow of ripe fruit'

toxó $P$ 'baggy, sack-like'

mox 'round and bulky, spherical'

pilo? 'turned up at brim'

pon?ó:? ‘bubbly, foamy'

stilé ? 'star-shaped'

s'ó:?o 'salty'

$\operatorname{tax}$ 'lit up, illuminated'

tsutsó? 'red'

Jkúta 'sour'

The words in (2) are clearly adverbs, as shown in (3):

(3) a. lantá? tato:kanáił naktfiwíf lakstín

lantá? ta-ta-waka-na:n-1 nak=t fiwíf

flat.on.belly 3PL.SUB-INCH-be.high-ST.PL-PFV LOC=rock 


\section{Arguments in Upper Necaxa Totonac}

lakstín

children

'the children are lying on their bellies on the rock' (CF)

b. pilo?tsá la:ł kintǻ?nu

pilớ $=$ =tsá la:-1 kin-tắinu

turned.up=now do-PFV 1PO-hat

'my hat has got its brim turned up' (RM)

c. mox wakáa ifma:sé? ?o:fúm

mox wakắq if-ma:sé? Po:fúm

round be.high 3PO-nest wasp

'the wasp nest is up there all big and round' (SC)

d. Skúta kinkaán t $\int a u M$

Skúta kinka-an- $\varnothing \quad$ t $\int a u M$

sour nose-go-IMPF tortilla

'the tortilla smells sour' (LB)

As seen in these examples, the descriptive adverbs appear in the pre-verbal slot generally reserved for verbal modifiers such as adverbs, ideophones, and adverbial particles. Not coincidentally, adjectives also can appear in this position in some constructions:

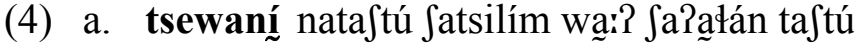

tsewaní na-ta-ftú Ja-tsilím wa:?

beautiful FUT-INCH-out DTV-crackling completely

$$
\begin{array}{ll}
\text { Sa-Pałá-n } & \text { ta-Stú } \\
\text { DTV-big-PL } & \text { INCH-out }
\end{array}
$$

'the pork cracklings will be beautiful, just big ones will come out' (RM)

Syntactically, however, adjectives are distinguishable from adverbs in that they are unmarked modifiers of nouns (Beck 2000, 2002), whereas adverbs are not:

a. mat tama:Stumąiná:ł naiftuxán ạitín Pạa tạ t tiwíf

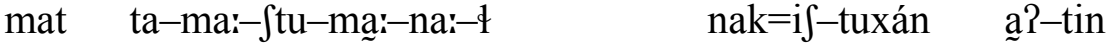

$$
\begin{aligned}
& \text { QTV 3PL.SUB-CS-out-PRG-ST.PL-PFV LOC=3PO-foot CLS-one } \\
& \text { ?ắa t tiwíf } \\
& \text { big rock }
\end{aligned}
$$


b. *ka:ná: wilé⿱ił kíwi i

*'a very twisted tree' (LB)

c. ka:ná: wilę́Płwa kî́wi

ka:ná: wilę́?t-wa kíwi

truly twisted-SEM tree

'a very twisted tree' (LB)

The adjective in (5a) functions as an adnominal modifier, while the adverb in (5b) is ungrammatical in this position. As shown in $(5 \mathrm{c})$, adverbs require the semblative suffix - wa to appear in this position.

Even though adverbs and adjectives are separate parts of speech, they show considerable functional overlap:

(6) a. ka:ná: wilệ́fł stắkli kíwi

ka:ná: wilę́fł stãk-li kíwi

truly twisted grow-PFV tree

'the tree grew very twisted' (LB)

b. ka:ná: wilệPłwa stákli kíwi

ka:ná: wilếi-wa stak-li kíwi

truly twisted-SEM grow-PFV tree

'the tree grew very twisted' (LB)

These two sentences are synonymous: (6a) does not seem to be amenable to a gloss such as 'the tree grew twistedly', nor is (6b) amenable to a gloss such as 'the twisted tree grew'. Instead, both qualifiers attribute a property to the subject of the sentence and both function as "small clause" predicate complements. Thus, descriptive qualities can be attributed to arguments by the adjunction of modifying elements to a verbal predicate in much the same way that grammatical categories such as nominal number are indicated morphologically on the verb.

\section{Inflection, Agreement and Quantification in UNT}

\subsection{Nominal Number}

NPs in UNT are only optionally marked for number using a variety of pluralizing affixes, most commonly / $\mathrm{n}(\mathrm{V}) /$ where $\mathrm{V}$ is a harmonic copy of the last vowel in the stem (Beck 2004):

(7) $t$ fik 'house' matát 'mushroom' pi:jká:'t'civic official' akakulút'scorpion' stáya 'squirrel' $>\quad$ tfikni 'houses'

$>\quad$ ma đátna 'mushrooms'

$>\quad$ pi:fká:Ina 'civic officials'

$>\quad$ akakulútnu 'scorpions'

$>\quad$ stayán 'squirrels' 


$$
\begin{array}{lll}
\text { slulúku 'lizard' } & > & \text { slulukún 'lizards' } \\
\text { púksni 'Spanish cedar' } & > & \text { puksnin 'Spanish cedars' }
\end{array}
$$

As shown by these examples, C-final stems take the [-nV] form of the suffix while V-final stems simply take [-n]. Most nouns referring to humans, animal names, and bodyparts use the suffix -nin:

\begin{tabular}{|c|c|c|}
\hline kimakán 'my hand' & $>$ & kimakanín 'my hands' \\
\hline kilákni 'my lower leg' & $>$ & kilaknín 'my lower legs' \\
\hline kutfu.mún 'doctor' & $>$ & kutfu.nunín 'doctors' \\
\hline pufnún 'picker' & $>$ & pufnunín 'pickers' \\
\hline ma:Rełtawa Pe.ní 'teacher' & $>$ & ma:Rettawa Pe:ninin 'teachers' \\
\hline lu.ntún 'lame person' & $>$ & lu.ntunín 'Tlame people' \\
\hline
\end{tabular}

(8)

However, despite the fact that it is possible to pluralize nouns, speakers rarely choose that option: plurals of non-humans are textually infrequent, and some younger speakers are unable to reliably produce these forms. What this means is that number-marking of nouns is not inflectional (i.e., an obligatory grammatical category), but is rather quasi-inflectional (Mel'čuk 1993-2000, 2006).

\subsection{Verbal Number}

Transitive verbs in UNT agree in person and number with their subject and objects:

(9) a. iklẫtsiná:므

ik-laitsín-ya:- $\underline{\mathbf{n}}$

1SG.SUB-See-IMPF-2OBJ

'I see you'

\section{b. kintalaitsín \\ kin- - ta- - la?tsín- $\varnothing$ \\ 1OBJ-3PL.SUB-See-IMPF \\ 'they see me'}

Number and person of subject are marked cumulatively by a single affix.

$$
\begin{array}{lll}
i k-\text { ''1SG.SUB' } & -t /-V \text { '2SG.SUB' } & \varnothing \text { '3SG.SUB' } \\
-w \text { '1PL.SUB' } & -t i t \text { '2PL.SUB' } & t a-\text { '3PL.SUB' }
\end{array}
$$

Number and person of objects are marked by separate affixes:

$$
\begin{aligned}
& \text { Person: kin- '1OBJ' } \quad \text { Number: } \varnothing \text { 'SG.OBJ' } \\
& -n \text { '2OBJ' } k a: \text { ' 'PL.OBJ' }
\end{aligned}
$$




\section{David Beck}

Thus, plurality of first- and second-person objects is marked by a combination of two affixes, as in (10):

(10) a. kaitalątsiná:므

ka:-ta-lâtsín-ya:-n

$\underline{\text { PL.OBJ-3PL.SUB-See-IMPF-2OBJ }}$

'they see you guys'

b. kinkartalẫ tsiná:n

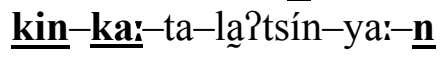

$\underline{\text { 1OBJ-PL.OBJ-3PL.SUB-See-IMPF-2OBJ }}$

'they see us'

Agreement is obligatory in person for all arguments and in number for all animate arguments; however, number-marking on NPs is optional (in fact, dispreferred):

(11) a. ika:putsayá:um t tit $\int_{\sim}^{i}$

ik-ka:-putsá-ya:-w t tit $\int_{\sim}^{\prime}$

1SG.SUB-PL-search-IMPF-1 PL.SUB dog

'we ExC look for the dogs'

b. ika:putsayá:um t $\int \mathrm{it} \iint_{\sim}^{\prime} \mathrm{n}$

ik-ka:-putsá-ya:-w t titfí -n

1SG.SUB-PL-search-IMPF-1PL.SUB dog-PL

'we $\mathrm{ExC}$ look for the dogs'

When both subject and object are third-person, the number of only one can be marked on the verb; the number of the other is optionally marked on the NP:

(12) a. taputsá t tit $\int_{\sim}^{\prime}$

ta-putsá-Ø t

3PL.SUB-search-IMPF dog

'they look for the dog/dogs'

b. taputsá t $\int i t \iint_{\sim}^{\prime} n$

ta-putsá-Ø t $\varnothing \mathrm{it} \int_{\sim}^{1}-\mathrm{n}$

3PL.SUB-search-IMPF dog-PL

'they look for the dogs'

c. * Slakán putsá t t it $\iint_{\sim}^{\prime}(n)$

'they (Jlakán) look for the $\operatorname{dog}(\mathrm{s})$ ' 
d. ka:putsá t fit $\int_{\sim}^{\prime}$

ka:-putsá-Ø t $\quad$ tjit $\int_{\sim}^{\prime}$

PL.OBJ-Search-IMPF dog

's/he/they look for the dogs'

e. ka:putsá tfitfín

ka:-putsá-Ø t $\varnothing \mathrm{it} \int \underline{a}-\mathrm{n}$

PL.OBJ-search-IMPF dog-PL

's/he/they look for the dogs'

f. *taka:putsá t fitfín (n)

'they look for the $\operatorname{dog}(\mathrm{s})$ '

The sentences in (12a) and (12d) are preferred, the choice between the forms depending on the relative discourse salience of the subject and object. (12b) and (12e) are possible, though uncommon, while the form *taka:putsá is ungrammatical (12f). The form putsá in this context would also be ungrammatical (12c), showing that number-marking of NP arguments is an inflectional (i.e., obligatory) category of verbs, although there are some restrictions on it (see Beck 2001 for further discussion).

\subsection{Other Types of Quantification in Verbs}

In addition to requiring the number of NP arguments to be marked on the verb, UNT can also quantify the verb's arguments with the quasi-inflectional suffix -?o: 'totalitative':

(13) namakftimi:?o:tsá kinkapéx

na-makStimí:- $\underline{-10}-\varnothing=$-tsá $\quad$ kin-kapéx

FUT-be.piled.evenly- - OT-IMPF $=$ now 1 PO-coffee

'now my coffee is going to be all piled up evenly' (LB)

The totalitative suffix is especially interesting in that its position relative to other morphemes in the verb varies, depending on what particular element in the clause it quantifies - the event (14a), the subject (14b), or the object (14c) (Beck, Holden, \& Varela n.d.):

(14) a. natawa? $\underline{0}$ kutuma:ná:4

na-ta-wa- $\underline{0}$ :-kutun-ma:--na:n-li

FUT-3PL.SUB-eat-TOT-DSD-PROG-ST.PL-PFV

'they are wanting to eat everything up' 


\section{David Beck}

b. natawakutumari?onná:

na-ta-wa-kutun-mą:- - o:-na:n-li

FUT-3PL.SUB-eat-DSD-PROG-TOT-ST.PL-PFV

'everyone is wanting to eat'

c. natawakutuma:na:n?ó:

na-ta-wa-kutun-ma:-na:n- - o:- - - $i$

FUT-3PL.SUB-eat-DSD-PROG-ST.PL-

'they are wanting to try [i.e., eat] everything'

As with the attribution of properties to NPs, quantification can be carried out by ad-verbal elements whose semantic effects "filter down" to the verbal arguments.

\subsection{Marking of Semantic Roles of Arguments}

UNT lacks prepositions and marks the semantic roles of arguments other than ACTOR and UNDERGOER using a range of applicative morphemes and bodypart prefixes (Beck 2004, 2006). For instance, the verb ta:litanká: ' $\mathrm{X}$ fells $\mathrm{Y}$ with $\mathrm{Z}$ aided by W' has a transitive base tanká: ' $\mathrm{X}$ fells $\mathrm{Y}$ ' and contains two applicatives, the comitative $t a{ }^{\prime}$ - and the instrumental $l i{ }^{\prime}$, subcategorizing for three objects:

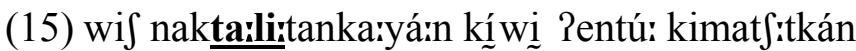

$\begin{array}{llll}\text { wif } & \text { na-ik-ta:-li:-tanká:-ya:-n } & \text { kíwi } & \text { Ren-tú: } \\ \text { you } & \text { FUT-1SG.SUB-CMT-INST-fell-IMPF-2OBJ } & \text { tree } & \text { CLS-two }\end{array}$

kin-matfí:t-kan

1PO-machete-PL.POS

'I and you are going to fell the tree with our two machetes'

Likewise, the verb ta.pu:la Imakamín ' $\mathrm{X}$ directs $\mathrm{Y}$ at $\mathrm{Z}$ using $\mathrm{W}$ aided by $\mathrm{A}$ ' has a transitive base, makamin ' $\mathrm{X}$ throws/sends $\mathrm{Y}$ ', and contains three applicatives the comitative ta:-, $p u^{-}$- 'containing instrument', and the allative applicative la? In all, it subcategorizes for four objects:

(16) ika:ta:pu:la?makaminá:n t tiwíi kistánku kintsakatkán

ik-ka:-ta:-pu:-la? -makamín-ya:-n

t fiwís kin-stánku

1SG.SUB-PL.OBJ-CMT-CTD-ALTV-direct-IMPF-2OBJ stone 1PO-brother

kin-tsakát-kan

1 PO-sling-PL.PO

'I and my brother throw stones at you guys with our slings'

In clauses like these, the applicatives mark the grammatical relation and semantic role of the arguments. There is no case or other marking within the NP for this purpose, nor are there prepositions. Instead, information about the semantic and 


\section{Arguments in Upper Necaxa Totonac}

syntactic roles of the NPs in the clause is encoded on the verb rather than by separate lexical elements or morphology associated with the noun.

\section{Head-Marking and Beyond in UNT}

Upper Necaxa Totonac shows a strong preference for the "loading" of information into the predicate phrase, including information about the arguments of that predicate. Verbs are inflected for number of their arguments; number is not inflectional for nouns and nouns can be quantified by verbal affixes. The semantic roles of NPs are indicated by derivational means, and the language has a dedicated class of adverbs for attributing properties to NPs.

The first of these three characteristics, and to a lesser extent the second two, are familiar from the typology of polysynthetic languages and fall under what Nichols (1986) terms "head-marking" of syntactic relations:

Head-marking relations: for a pair of elements $\mathrm{X}$ and $\mathrm{Y}$ where $\mathrm{Y}$ is a syntactic dependent of $\mathrm{X}$, their syntactic relation is indicated by some morphosyntactic feature of X.

The most frequently observed types of head-marking involve encoding of either semantically "empty" structural information about the relation between head and dependent (e.g., possessive markers), or information about inherent semantic or grammatical features of the dependent (e.g., person/number agreement). UNT, however, seems to exemplify a third type of relation in which additional semantic or grammatical information not inherent to the dependent or its structural configuration is marked on the head (or in the phrase governed by the head).

This is seen most clearly in the quantificational effects of the totalitative suffix, which conforms to the strict definition of head-marking. However, the use of descriptive adverbs seems also to conform - if not to the letter - to the spirit of head-marking in that qualification of an argument is carried out by an element within the predicate phrase. It may be that future typological investigation of other strongly head-marking languages will reveal the presence of lexical and quasi-inflectional strategies for argument quantification and qualification similar to those found in Upper Necaxa Totonac.

\section{References}

Beck, David. 2000. The Syntax, Semantics, and Typology of Adjectives in Upper Necaxa Totonac. Linguistic Typology 4:213-250.

Beck, David. 2001. Person-Hierarchies and the Origin of Asymmetries in Totonac Verbal Paradigms. Linguistica Atlantica 23:1-33.

Beck, David. 2002. The Typology of Parts of Speech Systems: The Markedness of Adjectives. New York: Routledge.

Beck, David. 2004. Upper Necaxa Totonac. Munich: LINCOM Europa. 
Beck, David. 2006. Control of Agreement in Multi-Object Constructions in Upper Necaxa Totonac. In A. Fujimori and M. A. Reis Silva, eds., Proceedings of the 11th Workshop on Structure and Constituency in the Languages of the Americas, 1-11. Vancouver: University of British Columbia Working Papers in Linguistics.

Beck, David. to appear. Ideophones, Adverbs, and Predicate Qualification in Upper Necaxa Totonac. International Journal of American Linguistics.

Beck, David, Joshua Holden, and Vianey Varela. n.d. Upper Necaxa Totonac Non-Derivational Morphology.

Mel'čuk, Igor A. 1993-2000. Cours De Morphologie Générale. Montreal: Presses de l'Université de Montréal.

Mel'čuk, Igor A. 2006. Aspects of the Theory of Morphology. Berlin: Mouton de Gruyter.

Nichols, Johanna. 1986. Head-Marking and Dependent-Marking Grammar. Language 62:56-119.

Thompson, Sandra A. 1988. A Discourse Approach to the Cross-Linguistic Category "Adjective". In J. A. Hawkins, ed., Explaining Language Universals, 167-85. Oxford: Blackwell.

Department of Linguistics, University of Alberta

4-45 Assiniboia Hall

Edmonton, T6G 2E7

http://www.ualberta.ca/ dbeck

http://www.arts.ualberta.ca/ totonaco

dbeck@ualberta.ca 